\title{
Walnut Shell Biochar Increases Seed Germination and Early Growth of Seedlings of Fodder Crops
}

\author{
Omer Suha Uslu ${ }^{1}\left(\mathbb{D}\right.$, Emre Babur ${ }^{2}\left(\mathbb{D}\right.$, Mehmet Hakkı Alma $^{3}$ and Zakaria M. Solaiman ${ }^{4, *} \mathbb{C}$ \\ 1 Field Crops Department, Agriculture Faculty, Kahramanmaras Sutcu Imam University, \\ Kahramanmaraş 46050, Turkey; suhauslu@ksu.edu.tr \\ 2 Soil and Ecology Department, Faculty of Forestry, Kahramanmaras Sutcu Imam University, \\ Kahramanmaraş 46050, Turkey; emrebabur@ksu.edu.tr \\ 3 Department of Forest Industry Engineering, Kahramanmaras Sutcu Imam University, \\ Kahramanmaras 46050, Turkey; mhalma@yahoo.com \\ 4 The UWA Institute of Agriculture and UWA School of Agriculture and Environment, \\ University of Western Australia, Perth, WA 6009, Australia \\ * Correspondence: zakaria.solaiman@uwa.edu.au
}

Received: 13 September 2020; Accepted: 22 September 2020; Published: 24 September 2020

\begin{abstract}
Currently, biochars are produced from a wide range of feedstocks with a broad diversity in physicochemical characteristics. Therefore, a diverse agronomic response of crop plants to biochars application was expected. A preliminary ecotoxicological assessment is necessary before application of biochar to soil, even though biochar is a recalcitrant carbon considered as a promising soil amendment because of its ability to climate change mitigation by sequestration of carbon in the soil. Thus, a Petri dish germination test was conducted to assess the effects of six walnut shell biochar rates (i.e., $0,10,20$, 40,80 , and $120 \mathrm{Mg} \mathrm{ha}^{-1}$ ) on seed germination and early growth of seedlings of fodder crops (Triticale cultivar X Triticasecale Wittmack and Pisum sativum sp. arvense L. varieties Taşkent and Özkaynak). A simple Petri dish bioassay method used to determine the effect of biochar rates on seed germination. Germination rate decreased with both higher and lower rate of biochar application. Results showed that the germination rate and growth indices were dependent on plant species. The seed germination rate of all three species was stimulated at the $40 \mathrm{Mg} \mathrm{ha}^{-1}$ rate, but Taşkent mung bean occurred at the highest rate of $120 \mathrm{Mg} \mathrm{ha}^{-1}$. Significantly higher germination rate and growth indices observed with the 40 and $80 \mathrm{Mg} \mathrm{ha}^{-1}$ biochar rates, respectively. Biochar application generally increased seed germination at rates $\leq 40 \mathrm{Mg} \mathrm{ha}^{-1}$ and seedling growth indices at rates $\leq 80 \mathrm{Mg} \mathrm{ha}^{-1}$. This rapid test can be used as the first indicator of biochar effects on seed germination rate and early growth of seedlings. Farmers could use this test before investing in biochar application.
\end{abstract}

Keywords: biochar application; plant species; Petri dishes bioassay; fertilization

\section{Introduction}

Nutrient and water scarcity are major stress factors affecting seed germination and plant growth $[1,2]$. Germination in both annual and perennial plants and critical periods for yield determination in annual crops are among the most crucial stages in the development of plants [3-6]. Thus, seed germination and seedling growth properties are essential parameters for plant establishment which can be used as early and rapid indicators of the influences of the precision application on plant yield [7].

Timely and balanced addition of nutrients like $\mathrm{N}$ and $\mathrm{P}$ from anthropogenic sources are essential to optimize plant growth in several plant species [8-11]. However, repeated use of supra-optimum rates of synthetic fertilizers is economically expensive and environmentally detrimental [12-14]. Organic fertilization and use of $\mathrm{N}$-fixing species, on the other hand, are more environmentally friendly 
management tools that have been extensively studied over the last 30 years [15-19]. Use of organic fertilizers and amendments such as biochar was recognized as essential to achieving agricultural sustainability in modern cropping systems because of the intensive land use and land degradation in recent years $[7,20]$. Biochar is a carbon-rich material produced after the pyrolysis of organic biomass [21] whose use has been globally proposed as an organic amendment to mitigate climate change by increasing carbon sequestration capacity in soils. Besides, biochar contributes to improving physicochemical and biological soil characteristics of soil health. As a result of an increase in soil health, biochar can have a positive effect on crop yields [21]. Field or pot application of varying rates of biochar has resulted in highly variable results, with an ample range of responses showing increases, decreases, or no changes in plant growth and biomass yield as a result of biochar application [22,23].

Biochars derived from different organic materials have been used to increase seed germination and improve soil fertility and other soil properties. Biochars have also been used to enhance plant productivity by minimizing the impact of abiotic stress factors such as drought through increased soil water holding capacity (WHC) and by maintaining the nutrient content through improved cation exchange capacity [15,24-26].

Moreover, the addition of biochar to soil may reduce the adverse effects of climate change by increasing soil carbon stocks by improving soil physicochemical properties like $\mathrm{pH}$, cation exchange capacity, soil water holding capacity, plant-nutrient retention, microbial activity, and nutrient availability [21,27-29]. Furthermore, biochar application can decrease bulk density and increase soil porosity which can significantly improve soil aeration and structure [30]. It helps to maintain plant nutrition through absorption and slow release of nutrients to plants and contributes to the reclamation of degraded soils [31]. He et al. [32] observed that biochar amendments contributed to increasing soil microbial activity and provided a suitable condition for nitrification. Biochar has also been used as a highly effective sorbent [33], that can reduce heavy metal concentrations and levels of other phytotoxic compounds that are harmful to plant development and seed germination by adsorption to their surface [34].

Studies have reported that biochar application may have both positive [24,29,35-37] and negative [38-40] effects on seed germination and seedling growth [41]. In this context, it is crucial to identify the proper biochar material for soil improvement and seed germination $[17,40]$. More research is needed to determine the relationship between different biochar materials and the germination process of different plant species. To this end, a simple approach involves the germination of seeds in Petri dishes in response to varying rates of biochar application. For instance, Solaiman et al. [15] utilized Petri dishes to investigate biochar effects on Triticum aestivum L. seed germination rate and early plant growth, and Rosende et al. [42] studied the effect of biochar applications to mine soil on germination of Lolium perenne L. seeds. Gascó et al. [40] conducted a Petri dish assay to determine the influence of phytotoxic compounds on germination rate for five plant species. Busch et al. [39] used a similar test to determine germination rates and plant growth indices with different hydrochars and biochars. This study reported that hydrochars severely inhibited seed germination. Hydrochar treatment caused abiotic stress by emitting phytotoxic gases and causing salt stress. In another study, the germination rate of maize was not significantly influenced by the biochar application [22].

Successful seed germination is crucial for both plant growth and development; therefore, germination rate and early growth characteristics can be an early indicator of the effects of biochar on plant productivity [7]. Such a laboratory bioassay test would be an excellent option to determine the usability of biochar in soil rehabilitation [21,43].

A seed germination test is a fast and reliable assay to determine the potential effects of biochar application on plant growth. Few studies were conducted to assess the impact of biochar on seed germination and plant growth due to the specificity of the interaction between biochars and plants. Therefore, the impact of biochar applications on seed germination should be determined before use in large-scale areas. For this, we applied a procedure used at the Oregon State University Seed Laboratory as a 'rapid test' for monitoring the effects of biochar on plant growth and seed germination. 
This study aimed to determine the impact of biochar application rate on seed germination rate and early plant productivity.

Walnut production in the world increased from 1.80 million $\mathrm{Mg}$ in 2005 to 3.75 million $\mathrm{Mg}$ in 2016. Approximately $90 \%$ of the walnut world production is grown in eight major producing countries, including China, USA, Iran, Turkey, Mexico, Ukraine, Chile, and Uzbekistan. Turkey, with an approximate production of $15,000 \mathrm{Mg} \mathrm{yr}^{-1}$, ranks fourth in the world for walnut production, with the province of Kahramanmaraş being the most important producer in the nation [43]. Therefore, walnut shell waste from walnut production would be a potential resource for biochar production in the province of Kahramanmaraş.

\section{Materials and Methods}

\subsection{Biochar Production and Characterization}

Biochar used in this study was produced at $550{ }^{\circ} \mathrm{C}$ from black walnut (Juglans nigra L.) shells. The pyrolysis duration was 120 min for walnut shells, and it was produced by using a Pyrolysis unit at Kahramanmaraş, Turkey. Biochars were sieved to pass a $2 \mathrm{~mm}$ screen [44] before use in soilless Petri dish bioassays. The $\mathrm{pH}$ and electrical conductivity (EC) of the biochar were determined in a 1:2.5 soil/water suspension with a $\mathrm{pH} / \mathrm{EC}$ meter by the methods of Rhoades [45]. WHC of biochar was determined by drying the biochar for $24 \mathrm{~h}$ at $105^{\circ} \mathrm{C}$ and then soaking it in water for $12 \mathrm{~h}$ [46]. WHC was calculated according to the equation: $\mathrm{WHC}=($ wet mass $\times 100) /$ dry mass.

On a powdered subsample of biochar, total carbon was determined by the Walkley-Black method [47], and total nitrogen was determined by the Kjeldahl method [48]. Elemental composition of biochar ( $\mathrm{Al}, \mathrm{B}, \mathrm{Ca}, \mathrm{Cd}, \mathrm{Co}, \mathrm{Cr}, \mathrm{Cu}, \mathrm{Fe}, \mathrm{K}, \mathrm{Mg}, \mathrm{Mn}, \mathrm{Na}, \mathrm{Ni}, \mathrm{P}, \mathrm{Pb}$, and $\mathrm{Zn}$ ) was measured using an ICP-OES Instrument (Agilent 5110). Before analysis, a $0.5 \mathrm{~g}$ sample of biochar was digested with $5 \mathrm{~mL}$ of $\mathrm{HNO}_{3}$ and $4 \mathrm{~mL}$ of $\mathrm{HClO}_{4}$ in a hot plate system and diluted to $25 \mathrm{~mL}$ with deionized water. After that, the prepared solutions were filtered (Whatman 42) and stored in the freezer until analysis [49].

\subsection{Biochar Bioassay for Fodder Seeds}

The pretreatment and bioassay were conducted in an incubator of the Kahramanmaras Sutcu Imam University, Faculty of Agriculture, Department of Field Crops Laboratory in September 2018. Three plant genotypes (one genotype of $\mathrm{x}$ Triticasecale Wittmack, Tritikale and two genotypes of Pisum sativum sp. arvense L. namely Taşkent and Özkaynak) were used in this bioassay. The study was arranged as a completely randomized design (CRD) with four replications, each Petri dish being a replication. The fodder seeds used in the study were sterilized in $5 \% \mathrm{NaClO}$ (sodium hypochlorite) solution for $5 \mathrm{~min}$ and then rinsed with distilled water. Different biochar doses $(0,0.5,1.0,2.0,4.0$, and $6.0 \mathrm{~g}$ per Petri dish equivalent to $0,10,20,40,80$, and $120 \mathrm{Mg} \mathrm{ha}^{-1}$ on a volume basis at $10 \mathrm{~cm}$ soil depth) were added to the Petri dishes on filter paper moistened with $20 \mathrm{~mL}$ distilled water [50]. In other words, these ratios are equal to $0 \%, 0.03 \%, 0.06 \%, 0.12 \%, 0.24 \%$, and $0.36 \%$ of the soil mass, assuming a bulk density of $1.6 \mathrm{~g} \mathrm{~cm}^{-3}$ [51]. Twenty-five seeds were spread per Petri dish of $90 \mathrm{~mm}$ diameter, and $20 \mathrm{~mL}$ of distilled water was added to each Petri dish. Then, Petri dishes were closed with lids, sealed and incubated in the dark at $25^{\circ} \mathrm{C}$ for $14 \mathrm{~d}$, after which the germination rate and other early growth properties were evaluated. During the length of the experiment, all Petri dishes were examined every other day, and equal amounts of distilled water were added according to the need for the filter paper not to dry [52].

Germination rate, radicle length, plumula length, seedling fresh weight, dry seedling weight, and vigor index values were measured. The germination rate was calculated by dividing the amount of germinated seeds by the total number of seeds and then multiplying by 100 [53]. The radicle and plumula lengths were measured separately, and then both lengths measured as seedling length [54]. The radicle and plumula fresh weights were obtained, dried at $70{ }^{\circ} \mathrm{C}$ for $24 \mathrm{~h}$ and weighed to 
determine seedling dry weight [54]. Vigor index was determined by multiplying the seedling length by germination rate $[55,56]$.

\subsection{Statistical Analysis}

For the Petri dish bioassay, a two-way analysis of variance (ANOVA) was performed using SAS 9.3 to determine the main effects of factors (species and biochar doses) as well as their interactions. Also, ANOVA was used to find the significance of seed germination with different biochar rates. Means comparisons among treatments were made using LSD at the $p \leq 0.05$ level [57]. Correlation matrix analysis was conducted among the seed germination, seedling growth, and biochar characteristics of the laboratory bioassay.

\section{Results}

\subsection{Biochar Properties}

The main characteristics of the tested biochar are stated in Table 1 . The mean $\mathrm{pH}$ was 8.25 , which is moderately alkaline (7.9-8.4), according to the United States Department of Agriculture classification of $\mathrm{pH}$ ranges [58]. The mean EC was $570 \mu \mathrm{Scm}^{-1}$, which is in the non-saline range. The tested biochar had high organic carbon, and total nitrogen concentrations and the percentage of WHC were significant.

Table 1. Basic properties of biochar derived from a walnut shell.

\begin{tabular}{cccc}
\hline Properties & Mean & Properties & Mean \\
\hline $\mathrm{pH}(1: 2.5)$ & 8.25 & $\mathrm{Cu}(\mathrm{ppm})$ & 9.56 \\
$\mathrm{EC}\left(1: 2.5, \mu \mathrm{S} \mathrm{cm} \mathrm{cm}^{-1}\right)$ & 570.00 & $\mathrm{Fe}(\mathrm{ppm})$ & 328.44 \\
$\mathrm{OC}(\%)$ & 79.60 & $\mathrm{~K}(\mathrm{ppm})$ & 6132.38 \\
$\mathrm{TN}(\%)$ & 0.12 & $\mathrm{Mg}(\mathrm{ppm})$ & 596.25 \\
$\mathrm{WHC}(\%)$ & 61.29 & $\mathrm{Mn}(\mathrm{ppm})$ & 77.88 \\
$\mathrm{Al}(\mathrm{ppm})$ & 327.47 & $\mathrm{Na}(\mathrm{ppm})$ & 420.18 \\
$\mathrm{~B}(\mathrm{ppm})$ & 19.78 & $\mathrm{Ni}(\mathrm{ppm})$ & 7.52 \\
$\mathrm{Ca}(\mathrm{ppm})$ & 6648.85 & $\mathrm{P}(\mathrm{ppm})$ & 224.13 \\
$\mathrm{Cd}(\mathrm{ppm})$ & 0.02 & $\mathrm{~Pb}(\mathrm{ppm})$ & 1.46 \\
$\mathrm{Co}(\mathrm{ppm})$ & 0.22 & $\mathrm{Zn}(\mathrm{ppm})$ & 11.58 \\
$\mathrm{Cr}(\mathrm{ppm})$ & 5.20 & & \\
\hline
\end{tabular}

\subsection{Germination and Plant Development}

In this study, the germination rate and other seedling growth characteristics were significantly different for different fodder species and treatments. The germination rate of fodders originating from Taşkent $(94 \%)$ was significantly higher $(p<0.01)$ than Triticale $(81 \%)$ and similar to Özkaynak $(94 \%)$ species. Seed germination rate (\%) ranged from 69 to 97 across different biochar doses (Table 2, Figure 1a). The maximum germination rate $(97 \%)$ was found at 40 and $80 \mathrm{Mg} \mathrm{ha}^{-1}$ application for species of Taşkent origin whereas the minimum germination rate $(69 \%)$ was observed for $120 \mathrm{Mg}^{-1}$ application.

Table 2. Analysis of variance (ANOVA) of germination rate (GR), radicle length (RL), plumula length (PL), seedlings length (SL), seedling fresh weight (SFW), seedling dry weight (SDW), and vigor index

(VI) values for cultivar, biochar rate, and their interactions.

\begin{tabular}{cccccccc}
\hline ANOVA & GR (\%) & RL (cm) & PL (cm) & SL (cm) & SFW (g) & SDW (g) & VI \\
\hline Cultivar & $* *$ & $*$ & ns & ns & $*$ & $* *$ & $* *$ \\
Biochar & $*$ & $*$ & ns & $*$ & ns & $* *$ & $* *$ \\
Cultivar $\times$ Biochar & $*$ & $*$ & $*$ & $*$ & $*$ & $*$ & $*$ \\
\hline
\end{tabular}

**, * denote statistical significance at $p \leq 0.01$ and $p \leq 0.05$, respectively; ns, not significant. 

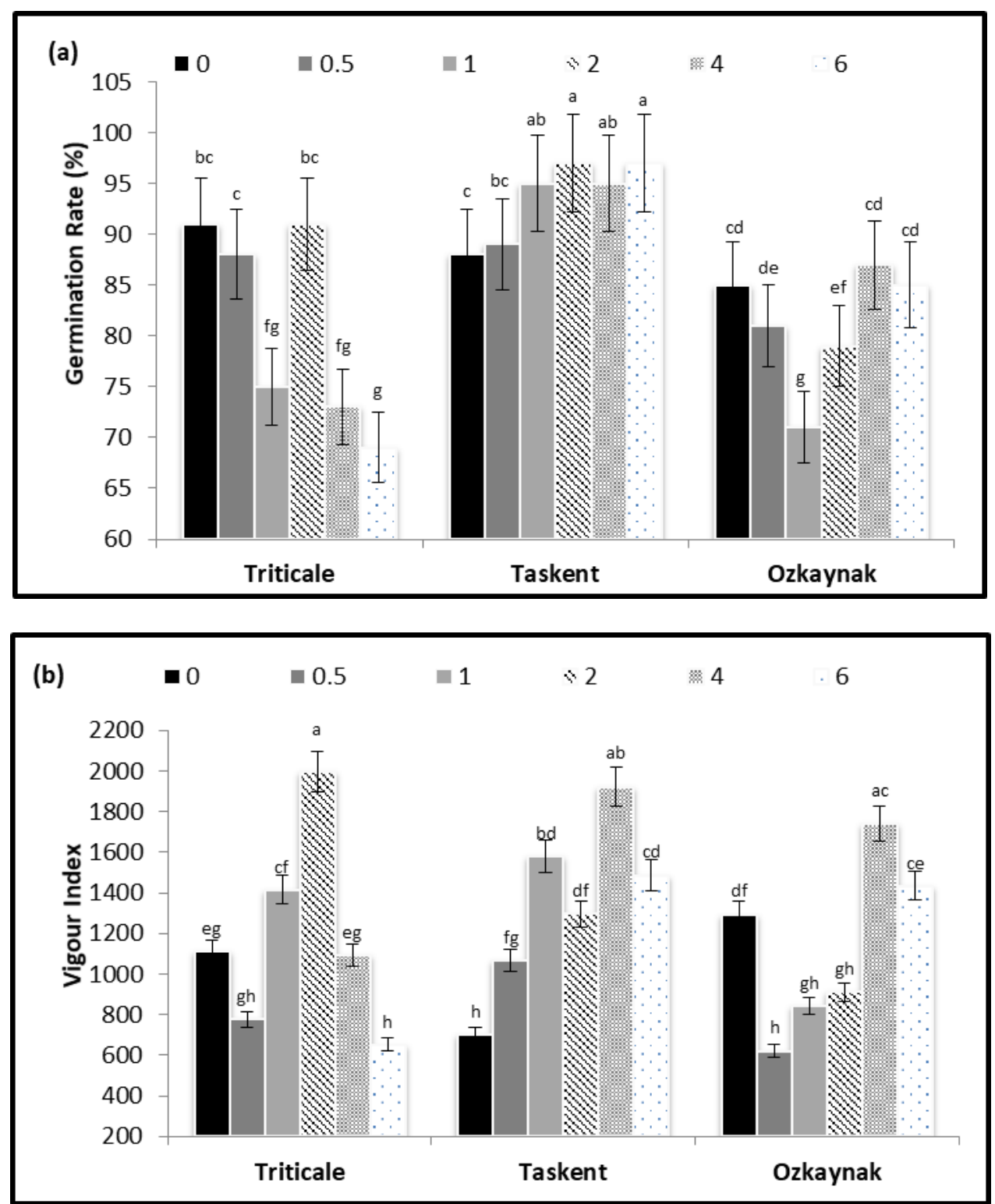

Figure 1. Effect of biochar rate on (a) germination rate (\%) and (b) vigor index of Triticale, Taşkent and Özkaynak. Different letters above the bars suggested that these values are significantly different at $p \leq 0.05$.

The highest values for germination rate were found at 0 and $40 \mathrm{Mg} \mathrm{ha}^{-1}$ for Triticale (91\%), 40 and $80 \mathrm{Mg} \mathrm{ha}^{-1}$ for Taşkent (97\%) and $80 \mathrm{Mg} \mathrm{ha}^{-1}$ for Özkaynak (87\%). When analyzing data from all three origins together, the most suitable biochar dose was found to be $40 \mathrm{Mg} \mathrm{ha}^{-1}$.

Radicle lengths were significantly different among the different treatments, with the longest radicle found in Triticale species (Table 2; Figure 2a). The maximum radicle length $(10.74 \mathrm{~cm})$ was found for $40 \mathrm{Mg} \mathrm{ha}^{-1}$ application for Triticale origin. Radicle lengths ranged from $1.82 \mathrm{~cm}$ to $10.74 \mathrm{~cm}$ across all biochar doses. The highest radicle length values were found in $40 \mathrm{Mg} \mathrm{ha}^{-1}$ application $(10.74 \mathrm{~cm})$ for Triticale origin, $80 \mathrm{Mg} \mathrm{ha}^{-1}$ application $\left(8.48 \mathrm{~cm}\right.$ ) for Tashkent origin and $80 \mathrm{Mg} \mathrm{ha}^{-1}$ application for Özkaynak source $(6.43 \mathrm{~cm})$. As a result of examining all three sources together, the highest root length was observed in $80 \mathrm{Mg} \mathrm{ha}^{-1}$ applications (Table 2; Figure 2a). 

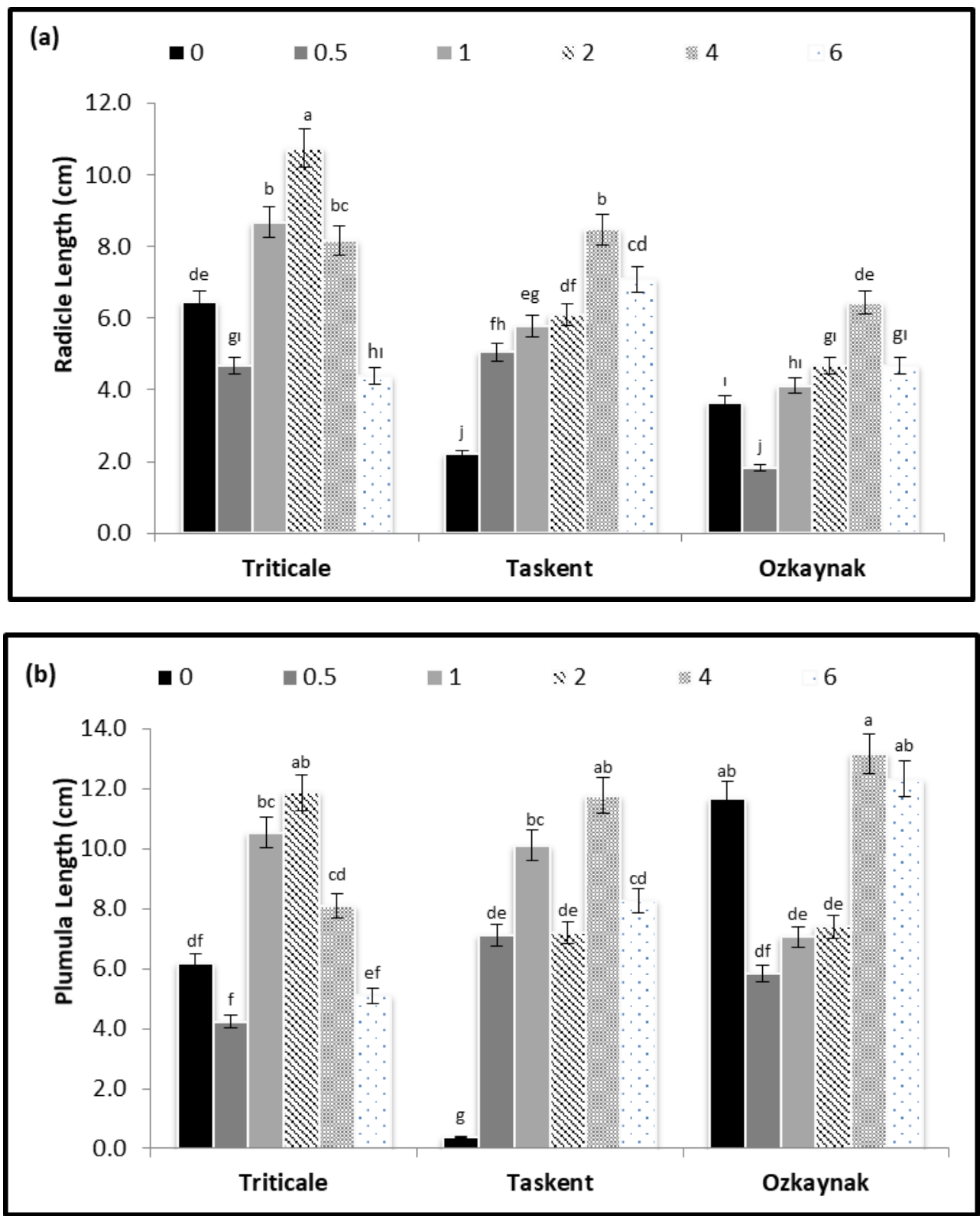

Figure 2. Effect of biochar rate on (a) radicle length, and (b) plumula length of Triticale, Taşkent and Özkaynak. Different letters above the bars suggested that these values are significantly different at $p \leq 0.05$.

Plumula lengths were significantly different among the different treatments. However, plumula and seedling lengths were not statistically different between the origins $(p>0.05)$. Also, the highest values of seedling fresh weights, seedling dry weights and vigor indices were found in Taşkent species. Plumula lengths ranged from $0.39 \mathrm{~cm}$ to $13.17 \mathrm{~cm}$ for all biochar doses. The highest plumula length was found in $40 \mathrm{Mg} \mathrm{ha}^{-1}$ application $(11.88 \mathrm{~cm})$ for Triticale origin, $80 \mathrm{Mg} \mathrm{ha}^{-1}$ application $(11.77 \mathrm{~cm})$ for Tashkent origin and $80 \mathrm{Mg} \mathrm{ha}^{-1}$ application for Özkaynak source $(13.17 \mathrm{~cm})$. Across all three sources, the highest plumula length was found in $80 \mathrm{Mg} \mathrm{ha}^{-1}$ applications (Table 2; Figure 2b).

Seedling lengths were significantly different among the different treatments. Seedling lengths ranged from $2.60 \mathrm{~cm}$ to $22.62 \mathrm{~cm}$ across all biochar doses. Seedling lengths were highest with Triticale origin for $40 \mathrm{Mg} \mathrm{ha}^{-1}(22.62 \mathrm{~cm}), 80 \mathrm{Mg} \mathrm{ha}^{-1}(20.25 \mathrm{~cm})$ for Taşkent source and $80 \mathrm{Mg} \mathrm{ha}^{-1}$ for Özkaynak 
source $(19.61 \mathrm{~cm})$. Across all three sources, the highest seedling length was found in $80 \mathrm{Mg} \mathrm{ha}^{-1}$ (Table 2; Figure 3a).
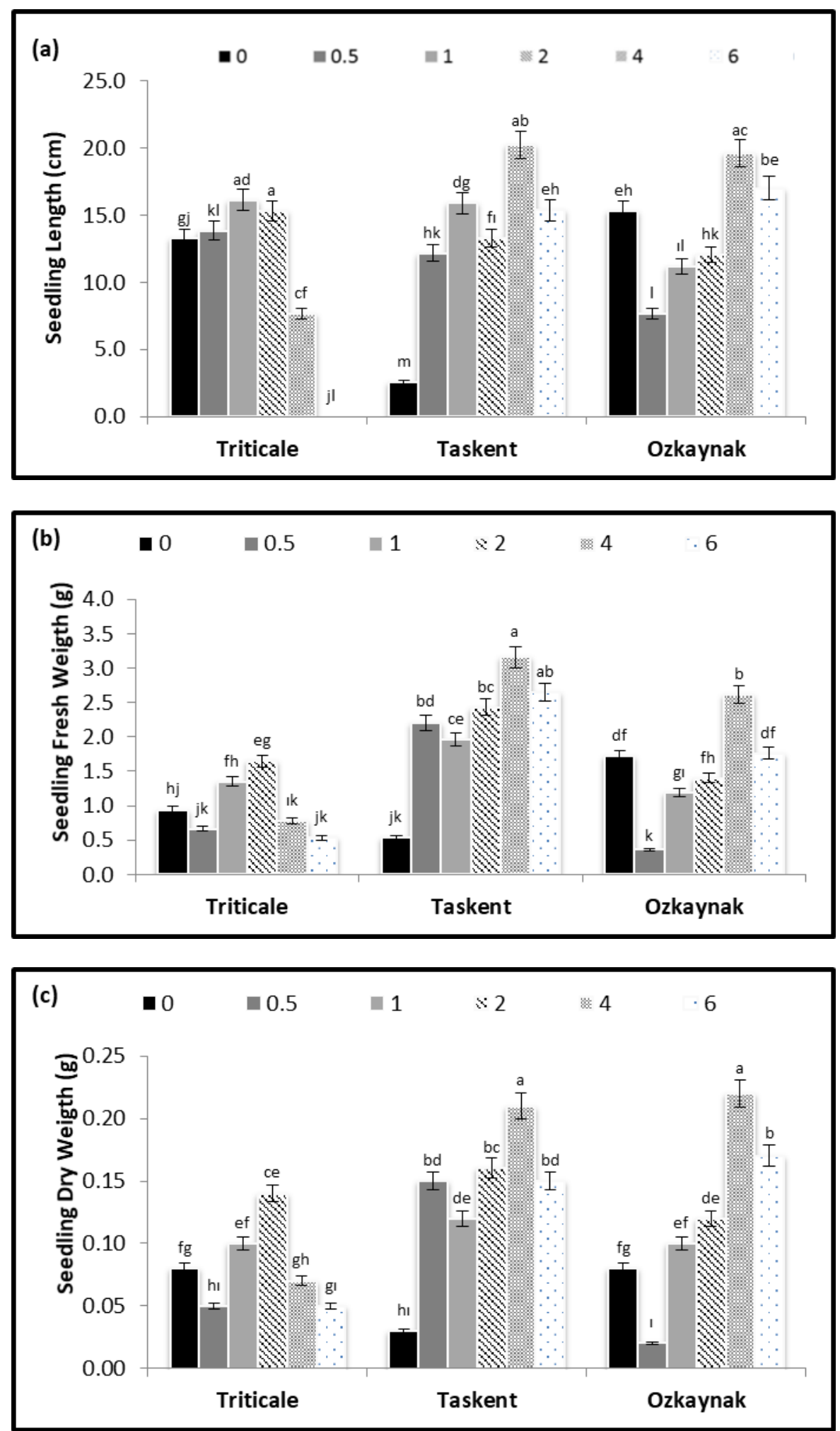

Figure 3. Effect of biochar rate on (a) seedling length, (b) seedling fresh weight, and (c) seedling dry weight of Triticale, Taşkent, and Özkaynak. Different letters above the bars suggested that these values are significantly different at $p \leq 0.05$. 
Seedling fresh weights were significantly different among the different treatments. Seedling fresh weights ranged from $0.36 \mathrm{~g}$ to $3.16 \mathrm{~g}$ across all biochar doses. The highest seedling fresh weights were found in $40 \mathrm{Mg} \mathrm{ha}^{-1}$ application (1.65 g) for Triticale origin, $80 \mathrm{Mg} \mathrm{ha}^{-1}$ application (3.16 g) for Taşkent origin and $80 \mathrm{Mg} \mathrm{ha}^{-1}$ application for Özkaynak origin $(2.61 \mathrm{~g})$. When analyzing all three origins together, the highest seeding fresh weight was found in $80 \mathrm{Mg} \mathrm{ha}^{-1}$ application (Table 2; Figure 3b).

Seedling dry weights were significantly different among the different treatments. Seedling dry weights ranged from $0.02 \mathrm{~g}$ to $0.22 \mathrm{~g}$ across all biochar doses application. The highest seedling dry weights were found in $40 \mathrm{Mg} \mathrm{ha}^{-1}$ application $(0.14 \mathrm{~g})$ for Triticale origin, $80 \mathrm{Mg} \mathrm{ha}^{-1}$ application $(0.21 \mathrm{~g})$ for Taşkent origin, and $80 \mathrm{Mg} \mathrm{ha}^{-1}$ application for Özkaynak origin $(0.22 \mathrm{~g})$. When analyzing all three origins together, the highest seedling dry weight was found in $80 \mathrm{Mg} \mathrm{ha}^{-1}$ application (Table 2; Figure 3c).

Seed vigor index showed a significant difference among the different treatments. Vigor index (VI) values ranged from 228 to 1998 across all biochar doses application. The highest vigor indexes were found in $40 \mathrm{Mg} \mathrm{ha}^{-1}$ application (1998) for Triticale origin, $80 \mathrm{Mg} \mathrm{ha}^{-1}$ application (1921) for Tashkent origin, and $80 \mathrm{Mg} \mathrm{ha}^{-1}$ application (1739) for Özkaynak origin (Table 2; Figure 1b). When analyzing all three origins together, the highest seed vigor index was found in $80 \mathrm{Mg} \mathrm{ha}^{-1}$ applications. The vigor index values correlated with seedling length and germination rate. The highest VI in the application of $40 \mathrm{Mg} \mathrm{ha}^{-1}$ for Triticale origin seeds might be due to the accumulative effect of higher germination rate and seedling length.

In the soil-less Petri dish bioassay, biochar application rates had a significant effect on seed germination $(p<0.05$, Table 2). Biochar application positively influenced seed germination and plant growth characteristics at the $80 \mathrm{Mg} \mathrm{ha}^{-1}$ application; however, germination and growth decreased at higher applications $(p<0.05$, Table 2$)$. Consequently, the most appropriate natural soil fertilization with biochar application was found to be $80 \mathrm{Mg} \mathrm{ha}^{-1}$ in an area of $10 \mathrm{~cm}$ soil depth for the species used in the experiment $(p<0.05)$, but higher biochar application rates led to negative impact $(p>0.05$; Table 2$)$.

Also, applying biochar to different species influenced seed germination rate and growth indexes $(p<0.05)$. For instance, Triticale and Taşkent species germination rate was found highest value in $40 \mathrm{Mg} \mathrm{ha}^{-1}$, but Özkaynak species germination rate was found highest value in $80 \mathrm{Mg} \mathrm{ha}^{-1}$. Increased biochar application rate generally increased radicle length, plumula length, seedling fresh weight, seedling dry weight, and vigor index of the seedlings in the Petri dish bioassay, especially at the $40 \mathrm{Mg} \mathrm{ha}^{-1}$ and $80 \mathrm{Mg} \mathrm{ha}^{-1}$ rates of application $(p<0.05$, Table 2$)$.

\section{Discussion}

While the rapid bioassay for germination rate and seedling growth indices were used for assessing the effect of biochar on the crop productivity on agricultural soils [15], it could be used to study the soil stressors. Biochar application to soil increases some soil properties such as $\mathrm{pH}$, water-holding capacity (WHC), soil organic carbon (SOC), and contributes to soil nutrient retention [59]. These positive effects can influence seed germination and plant productivity [60]. Nutrients were found in the biochar sample when applied to soils, some soil properties related to fertility improved. For example, Mendez et al. [61] found an increase in WHC after biochar application. Liang et al. [62] found that the amendment of soil with poultry litter biochar increased the resistance of soil microbial properties to drought sufficiently to increase agricultural yields. Lu et al. [63] reported that biochar increased the reaction $(\mathrm{pH})$ of acidic soil. Moreover, the combination of biochars and earthworms had a positive effect on soil microbial activities and plant growth [64].

In our study, the biochar $\mathrm{pH}$ was moderately alkaline. Not only high alkalinity but also strong acidity inhibits seed germination [65]. Chidumayo [66] noticed that biochar application to soil increased its $\mathrm{pH}$, exchangeable $\mathrm{P}$ and $\mathrm{K}$, and seed germination. Olszyk et al. [17] (2018) reported biochar application generally altered soil $\mathrm{pH}$ and EC. Biochar application can improve soil fertility and nutrient retention by increasing soil $\mathrm{pH}$, soil organic carbon, $\mathrm{Ca}, \mathrm{K}, \mathrm{Mn}$, soil exchangeable- $\mathrm{P}$, and other nutrients $[59,60]$. Also, biochar application had direct effects on soil properties, and its remediation such as Cely et al. [67] have been presented. Organic soil fertilizer application positively 
affects not only soil fertility but also plant biomass productivity. These effects depend on the quality of organic fertilizer.

The effect of biochar on the germination of plant species needs to be investigated before sowing $[15,68]$. In this study, the impact of biochar rate on seed germination and seedling growth indices varied among three agricultural plants (x Triticasecale Wittmack, Pisum sativum sp. arvense L. Taşkent and Özkaynak).

The results showed that the germination rate decreased with both higher and lower rates of biochar application. The optimum germination rate was found with $40 \mathrm{Mg} \mathrm{ha}^{-1}$ biochar application because the germination rate was not decreased compared to the control. Also, the results illustrated that the plant species significantly affected germination rate and growth indices. The seed germination rate of all three species was stimulated at the $40 \mathrm{Mg} \mathrm{ha}^{-1}$ application rate, but Taşkent mung bean occurred at the highest rate also in $120 \mathrm{Mg} \mathrm{ha}^{-1}$. Solaiman et al. [15] found that seed germination rates significantly influenced by biochar application similarly to our study. The germination rates generally increased at the lower rates $\left(10-50 \mathrm{Mg} \mathrm{ha}^{-1}\right)$ and decreased at higher rates of application $\left(>50 \mathrm{Mg} \mathrm{ha}^{-1}\right)$ $(p<0.05$, Table 2). Rondon et al. [69] stated that plant production and $\mathrm{N}$-fixation of common bean (Phaseolus vulgaris L.) yield increased with biochar application at 30 and $60 \mathrm{~g} \mathrm{~kg}^{-1}$ soil. However, there was a decrease in crop production as the biochar rate increased. In our study, we noticed that biochar application improved plant growth to be related to increased nutrient availability from biochar higher $\mathrm{pH}$ value.

Germination rate and seedling growth indexes such as plant height, root length, biomass accumulation, and Dickson quality index of okra were significantly influenced by biochar treatments [70]. Improving soil porosity and water holding capacity with biochar application contributed to increased root growth and high concentrations of nutrient uptake by the plant. It also helped to increase aboveground plant biomass [71,72].

The results of ANOVA test (Table 2) showed that germination rate and growth properties were influenced primarily by plant species. The germination rate was slightly higher in Pisum sativum sp. arvense L. Taşkent species. Olszyk et al. [17] reported that biochar application significantly influenced the germination rate of carrot, cucumber, and tomato species. As opposed to this, Gascó et al. [40] noticed that biochar application leads to decreased germination rate and early seedling growth.

Seedling growth indexes such as germination rate, radicle length, plumula length, seedling fresh weight, dry seedling weight, and vigor index values were slightly increased by biochar application in the present study and also reported elsewhere [17]. However, Gascó et al. [40] reported that different biochars have no effects on the seedling dry weight. Olszyk et al. [17] defined the impact of biochar on plant germination. It was determined that dry seedling weights of different plants significantly increased. Meng et al. [73] found no influence on germination rate but significant effect on older seedling fresh weight.

Consequently, the biochar rates generally increased seed germination at rates of application $<40 \mathrm{Mg} \mathrm{ha}^{-1}$ and a higher rate of biochar application inhibited seed germination under the bioassay conditions. This study recommended that the soil-less Petri dish bioassay would use for ecotoxicological test for biochar because it is rapid, simple, and inexpensive as mentioned in another study [15]. Moreover, there was a noticeable germination rate difference among plant species which also differed with different rates of biochar application. The information obtained from this study will increase our understanding of biochar applications on seed germination rate and seedling growth for their potential usage. Based on the obtained results of the present experiment, we suggest that the use of the soil-less Petri dish bioassay to determine possible effects of biochar on seed germination and early growth of fodder crops.

\section{Conclusions}

In conclusion, the rapid test investigated in this study demonstrated that biochar could increase seed germination and seedling growth with appropriate application rates. Taşkent species showed significant effects on germination as well as vigor index. Among the studied biochar doses, the use 
of $40 \mathrm{Mg} \mathrm{ha}^{-1}$ could be a better option to achieve enhanced germination rates and seedling growth indices. Agricultural areas are vast; preliminary laboratory studies may help before irreversible biochar application to the farm field. Therefore, the maximum crop yield can be obtained with efficient use of biochar and fertilizer with an economic return. Also, biochar application can provide a simple or immediate improvement to poor soil conditions such as $\mathrm{pH}, \mathrm{EC}, \mathrm{WHC}$, and some other properties. Besides, it contributes to carbon sequestration in soil which helps to reduce global warming [74].

Author Contributions: Conceptualization, O.S.U., E.B., M.H.A., and Z.M.S.; Methodology, O.S.U. and E.B.; Software, O.S.U.; Validation, O.S.U., E.B., M.H.A., and Z.M.S.; Formal analysis, O.S.U., E.B., M.H.A., and Z.M.S.; Investigation, O.S.U., E.B., and M.H.A.; Resources, X.X.; Data curation, X.X.; Writing-original draft preparation, O.S.U. and E.B.; Writing-review and editing, O.S.U., E.B., M.H.A., and Z.M.S.; Visualization, M.H.A.; Supervision and Project administration, O.S.U. and E.B.; Funding acquisition, O.S.U. All authors have read and agreed to the published version of the manuscript.

Funding: This research received no external funding.

Conflicts of Interest: The authors declare no conflict of interest.

\section{References}

1. Brevedan, R.E.; Egli, D.B. Short Period Water Stress during Seed Filling, Leaf Senescence and Yield of Soybean. Crop Sci. 2003, 43, 2083-2088.

2. Hamayun, M.; Khan, S.A.; Shinwari, Z.K.; Khan, A.L.; Ahmad, N.; Lee, I. Effect of Polyethylene Glycol Induced Drought Stress on Physio-Hormonal Attributes of Soybean. Pak. J. Bot. 2010, 42, 977-986.

3. Angevine, M.W.; Chabot, B.F. Seed Germination Syndromes in Higher Plants. In Topics in Plant Population Biology; Solbrig, O.T., Jain, S., Johnson, G.B., Raven, P.H., Eds.; Palgrave: London, UK, 1979. [CrossRef]

4. Baskin, C.C.; Baskin, J.M. Germination Ecophysiology of Herbaceous Plant Species in A Temperate Region. Amer. J. Bot. 1988, 75, 286-305. [CrossRef]

5. Battaglia, M.L.; Lee, C.; Thomason, W. Corn Yield Components and Yield Responses to Defoliation at Different Row Widths. Agron. J. 2018, 110, 1-16. [CrossRef]

6. Battaglia, M.L.; Lee, C.; Thomason, W.; Van Mullekom, J. Effects of Corn Row Width and Defoliation Timing and Intensity on Canopy Light Interception. Crop Sci. 2019, 59, 1718-1731. [CrossRef]

7. Rogovska, N.; Laird, D.; Cruse, R.M.; Trabue, S.; Heaton, E. Germination Tests for Assessing Biochar Quality. J. Environ. Qual. 2011, 41, 1014-1022.

8. Ketterings, Q.; Czymmek, K. Removal of Phosphorus by Field Crops; Agronomy Fact Sheet Series; Cornell University Cooperative Extension, 2007; Available online: http://nmsp.cals.cornell.edu/publications/ factsheets/factsheet28.pdf (accessed on 23 September 2020).

9. Kumar, P.; Lai, L.; Battaglia, M.L.; Kumar, S.; Owens, V.; Fike, J.; Galbraith, J.; Hong, C.O.; Faris, R.; Crawford, R.; et al. Impacts of Nitrogen Fertilization Rate and Landscape Position on Select Soil Properties in Switchgrass Field at Four Sites in the USA. CATENA 2019, 180, 183-193.

10. Kumar, S.; Lai, L.; Kumar, P.; Feliciano, Y.M.V.; Battaglia, M.L.; Hong, C.O.; Owens, V.N.; Fike, J.; Farris, R.; Galbraith, J. Impacts of Nitrogen Rate and Landscape Position on Soils and Switchgrass Root Growth Parameters. Agron. J. 2019, 111, 1046-1059.

11. Adeyemi, O.; Keshavarz-Afshar, R.; Jahanzad, E.; Battaglia, M.L.; Luo, Y.; Sadeghpour, A. Effect of Wheat Cover Crop and Split Nitrogen Application on Corn Yield and Nitrogen Use Efficiency. Agronomy 2020, 10, 1081. [CrossRef]

12. Khan, A.A.; Jilani, G.; Akhtar, M.S.; Naqvi, S.M.S.; Rasheed, M. Phosphorus Solubilizing Bacteria, Occurrence, Mechanisms and Their Role in Crop Production. J. Agric. Biol. Sci. 2009, 1, 48-58.

13. Battaglia, M.L.; Groover, G.; Thomason, W.E. Harvesting and Nutrient Replacement Costs Associated with Corn Stover Removal in Virginia. Va. Coop. Ext. Publ. 2018, CSES-229NP. Available online: https://www.pubs. ext.vt.edu/content/dam/pubs_ext_vt_edu/CSES/cses-229/CSES-229.pdf (accessed on 23 September 2020).

14. Czymmek, K.; Ketterings, Q.; Ros, M.; Battaglia, M.L.; Cela, S.; Crittenden, S.; Gates, D.; Walter, T.; Latessa, S.; Klaiber, L.; et al. The New York Phosphorus Index 2.0; Agronomy Fact Sheet Series; Cornell University Cooperative Extension, 2020; Available online: http:/nmsp.cals.cornell.edu/publications/ factsheets/factsheet110.pdf (accessed on 23 September 2020). 
15. Solaiman, Z.M.; Murphy, D.V.; Abbott, L.K. Biochars Influence Seed Germination and Early Growth of Seedlings. Plant Soil. 2012, 353, 273-287. [CrossRef]

16. Naeem, M.A.; Khalid, M.; Aon, M.; Abbas, G.; Tahir, M.; Amjad, M.; Murtaza, B.; Yang, A.; Akhtar, S.S. Effect of Wheat and Rice Straw Biochar Produced at Different Temperatures on Maize Growth and Nutrient Dynamics of A Calcareous Soil. Arch. Agron. Soil Sci. 2017, 63, 2048-2061. [CrossRef]

17. Olszyk, D.M.; Shiroyama, T.; Novak, J.M.; Johnson, M.G. A Rapid-Test for Screening Biochar Effects on Seed Germination. Commun. Soil Sci. Plan. 2018, 49, 2025-2041. [CrossRef]

18. Adnan, M.; Fahad, S.; Zamin, M.; Shah, S.; Mian, I.A.; Danish, S.; Zafar-ul-Hye, M.; Battaglia, M.L.; Naz, R.M.M.; Saeed, B.; et al. Coupling Phosphate-Solubilizing Bacteria with Phosphorus Supplements Improve Maize Phosphorus Acquisition and Growth under Lime Induced Salinity Stress. Plants 2020, 9, 900. [CrossRef] [PubMed]

19. Diatta, A.A.; Thomason, W.E.; Abaye, O.; Thompson, T.L.; Battaglia, M.L.; Vaughan, L.J.; Lo, M.; Leme, J.F.D.C. Assessment of Nitrogen Fixation by Mungbean Genotypes in Different Soil Textures Using 15N Natural Abundance Method. J. Soil Sci. Plant Nut. 2020. [CrossRef]

20. Diatta, A.A.; Fike, J.H.; Battaglia, M.L.; Galbraith, J.; Baig, M.B. Effects of Biochar on Soil Fertility and Crop Productivity in Arid Regions: A review. Arab. J. Geosci. 2020, 13, 595. [CrossRef]

21. Lehmann, J.; Joseph, S. Biochar for Environmental Management: Science and Technology, 1st ed.; Sterling, V.A., Ed.; Earthscan: London, UK, 2009.

22. Free, H.F.; McGill, C.R.; Rowarth, J.S.; Hedley, M.J. The Effect of Biochars on Maize (Zea Mays) Germination. N. Z. J. Agric. Res. 2010, 53, 1-4. [CrossRef]

23. Sänger, A.; Reibe, K.; Mumme, J.; Kaupenjohann, M.; Ellmer, F.; Roß, C.L.; Meyer-Aurich, A. Biochar Application to Sandy Soil: Effects of Different Biochars and N Fertilization on Crop Yields in A 3-Year Field Experiment. Arch. Agron. Soil Sci. 2017, 63, 213-229. [CrossRef]

24. Yamato, M.; Okimori, Y.; Wibowo, I.F.; Anshori, S.; Ogawa, M. Effect of the Application of Charred Bark of Acacia mangium on the Yield of Maize, Cowpea and Peanut, and Soil Chemical Properties in South Sumatra, Indonesia. Soil Sci. Plant Nut. 2006, 52, 489-495. [CrossRef]

25. Ronsse, F.; Van Hecke, S.; Dickinson, D.; Prins, W. Production and Characterization of Slow Pyrolysis Biochar: Influence of Feedstock Type and Pyrolysis Conditions. GCB Bioenergy 2013, 5, 104-115. [CrossRef]

26. Pluchon, N.; Gundale, M.J.; Nilsson, M.C.; Kardol, P.; Wardle, D.A. Stimulation of Boreal Tree Seedling Growth by Wood-Derived Charcoal: Effects of Charcoal Properties, Seedling Species and Soil Fertility. Funct. Ecol. 2014, 28, 766-775. [CrossRef]

27. Kammann, C.I.; Linsel, S.; Geoßling, J.W.; Koyro, H.W. Influence of Biochar on Drought Tolerance of Chenopodium quinoa Willd and on Soil Plant Relations. Plant Soil. 2011, 345, 195-210. [CrossRef]

28. Barrow, C.J. Biochar: Potential for Countering Land Degradation and for Improving Agriculture. Appl Geogr. 2012, 34, 21-28. [CrossRef]

29. Biederman, L.A.; Harpole, W.S. Biochar and Its Effects on Plant Productivity and Nutrient Cycling: A Meta-Analysis. GCB Bioenerg. 2013, 5, 202-214. [CrossRef]

30. Joseph, S.D.; Camps-Arbestain, M.; Lin, Y.; Munroe, P. An Investigation into the Reactions of Biochar in Soil. Soil Res. 2010, 48, 501-515. [CrossRef]

31. Sohi, S.P.; Krull, E.; Lopez-Capel, E.; Bol, R. A Review of Biochar and Its Use and Function in Soil. Adv. Agron. 2010, 105, 47-82.

32. He, L.; Zhao, X.; Wang, S.Q.; Xing, G.X. The Effects of Rice-Straw Biochar Addition on Nitrification Activity and Nitrous Oxide Emissions in Two Oxisols. Soil Till. Res. 2016, 164, 52-62. [CrossRef]

33. Sheng, G.; Yang, Y.; Huang, M.; Yang, K. Influence of pH on Pesticide Sorption by Soil Containing Wheat Residue-Derived Char. Environ. Pollut. 2005, 134, 457-463. [CrossRef]

34. Atkinson, J.A.; Fitzgerald, J.D.; Hipps, N.A. Potential Mechanisms for Achieving Agricultural Benefits from Biochar Application to Temperate Soils: A Review. Plant Soil. 2010, 337, 1-18. [CrossRef]

35. Wardle, D.A.; Zackrisson, O.; Nilsson, M.C. The Charcoal Effect on Boreal Forests: Mechanisms and Ecological Consequences. Oecologia 1998, 115, 419-426. [CrossRef]

36. Chan, K.Y.; Van Zwieten, L.; Meszaros, I.; Downie, A.; Joseph, S. Using Poultry Litter Biochars as Soil Amendments. Soil Res. 2008, 46, 437-444. [CrossRef] 
37. Jeffery, S.; Verheijen, F.G.A.; van der Velde, M.; Bastos, A.C. A Quantitative Review of the Effects of Biochar Application to Soils on Crop Productivity Using Meta-Analysis. Agric. Ecosyst. Environ. 2011, 144, $175-187$. [CrossRef]

38. Deenik, J.L.; McClellan, T.; Uehara, G.; Antal, M.J.; Campbell, S. Charcoal Volatile Matter Content Influences Plant Growth and Soil Nitrogen Transformations. Soil Sci. Soc. Am. J. 2010, 74, 1259-1270. [CrossRef]

39. Busch, D.; Kammann, C.; Grünhage, L.; Müller, C. Simple Biotoxicity Tests for Evaluation of Carbonaceous Soil Additives: Establishment and Reproducibility of Four Test Procedures. J. Environ. Qual. 2011, 40, 1-10. [CrossRef]

40. Gascó, G.; Cely, P.; Paz-Ferreiro, J.; Plaza, C.; Méndez, A. Relation between Biochar Properties and Effects on Seed Germination and Plant Development. Biol. Agric. Hortic. 2016, 32, 237-247. [CrossRef]

41. Kookana, R.S.; Sarmah, A.K.; Van Zwieten, L.; Krull, E.; Singh, B. Biochar Application to Soil: Agronomic and Environmental Benefits and Unintended Consequences. Adv. Agron. 2011, 112, 103-143.

42. Rosende, M.; Beesley, L.; Moreno-Jimenez, E.; Miró, M. Automatic Flow-Through Dynamic Extraction: A Fast Tool to Evaluate Char-Based Remediation of Multi-Element Contaminated Mine Soils. Talanta 2016, 148, 686-693. [CrossRef] [PubMed]

43. Sütyemez, M. Bitkisel Üretimde Kahramanmaraş. Kahramanmaraş ta Tarım Yaşam 2015, 4, 88.

44. Weidhuner, A.; Keshavarz Afshar, R.; Luo, Y.; Battaglia, M.; Sadeghpour, A. Sample Grinding Size Affects Nitrogen and Carbon Estimate of A Wheat Cover Crop. Agron. J. 2019, 111, 3398-3402. [CrossRef]

45. Rhoades, J.D. Electrical Conductivity Methods for Measuring and Mapping Soil Salinity. Adv. Agron. 1993, 49, 201-251.

46. G\&lser, C.; Pek\&en, A. Using Tea Waste as A New Casing Material in Mushroom (Agaricus Bisporus (L.) Sing.) Cultivation. Bioresour. Technol. 2003, 88, 153-156.

47. Walkley, A.; Black, A.I. An Examination of the Degtjareff Method for Determining Soil Organic Matter, and Proposed Modification of the Chromic Acid Titration Method. Soil Sci. 1934, 37, 29-38. [CrossRef]

48. Bremner, J.M.; Mulvaney, C.S. Nitrogen-total. In Methods of Soil Analysis; Page, A.L., Miller, R.H., Keeney, D.R., Eds.; American Society of Agronomy: Madison, WI, USA, 1982; pp. 595-624.

49. Jones, J.B., Jr.; Case, V.W. Sampling, handling, and analyzing plant tissue samples, chapter 15. In Soil Testing and Plant Analysis, 3rd ed.; Westerman, R.L., Ed.; SSSA: Madison, WI, USA, 1990; pp. 390-420.

50. Morrison, D.A.; Morris, E.C. Pseudoreplication in Experimental Designs for the Manipulation of Seed Germination Treatments. Austral. Ecol. 2000, 25, 292-296. [CrossRef]

51. Liao, S.; Pan, B.; Hao, L.; Zang, D.; Xing, B. Detecting Free Radicals in Biochars and Determining Their Ability to Inhibit the Germination and Growth of Corn, Wheat and Rice Seedlings. Environ. Sci. Technol. 2014, 48, 8581-8587. [CrossRef]

52. Solaiman, Z.M.; Blackwell, P.; Abbott, L.K.; Storer, P. Direct and Residual Effect of Biochar Application on Mycorrhizal Roocolonizationon, Growth and Nutrition of Wheat. Soil Res. 2010, 48, 546-554. [CrossRef]

53. Maquire, J.D. Speed of Germination Aid in Selection and Evaluation for Seedling Emergence and Vigor. Crop Sci. 1962, 2, 176-177. [CrossRef]

54. Anonymous. Association of Official Seed Analysts, Rules for Testing Seeds. J. Seed Tech. 1984, 6, 1-125.

55. Abdul-Baki, A.A.; Anderson, J.D. Vigor Determination in Soybean Seed by Multiple Criteria. Crop Sci. 1973, 13, 630-633. [CrossRef]

56. Anonymous. Association of Official Seed Analysts, Seed Vigor Testing Handbook; ADSA: Boise, ID, USA, 1983.

57. Steel, R.G.D.; Torrie, J.H. Principles and Procedures of Statistics; McGraw-Hill: New York, NY, USA, 1960; p. 481.

58. USDA. Natural Resources Conservation Service, Soil Quality Indicators: pH, January 1998. Available online: https://www.nrcs.usda.gov/Internet/FSE_DOCUMENTS/nrcs142p2_052208.pdf (accessed on 23 September 2020).

59. Lehmann, J.; Gaunt, J.; Rondon, M. Bio-Char Sequestration in Terrestrial Ecosystems. Mitig. Adapt. Strateg. Glob. Chang. 2006, 11, 403-427. [CrossRef]

60. Novak, J.M.; Lima, I.; Xing, B.; Gaskin, J.W. Characterization and Their Effects on A Loamy Sand. Annal. Environ. Sci. 2009, 3, 195-206.

61. Mendez, A.; Gomez, A.; Paz-Ferreiro, J.; Gasco, G. Effects of Sewage Sludge Biochar on Plant Metal Availability After Application to a Mediterranean Soil. Chemosphere 2012, 89, 1354-1359. [PubMed] 
62. Liang, C.; Zhu, X.; Fu, S.; Mendez, A.; Gasco, G.; Paz-Ferreiro, J. Biochar Alters the Resistance and Resilience to Drought in A Tropical Soil. Environ. Res. Lett. 2014, 9, 064013.

63. Lu, H.; Li, Z.; Fu, S.; Mendez, A.; Gasco, G.; Paz-Ferreiro, J. Combining phtoextraction and Biochar Addition Improves Soil Biochemical Properties in A Soil Contaminated with Cd. Chemosphere 2015, 119, 209-216.

64. Paz-Ferreiro, J.; Fu, S.; Mendez, A.; Gasco, G. Interactive Effects of Biochar and the Earthworm Pontoscolex Corethrurus on Plant Productivity and Soil Enzyme Activities. J. Soil Sediment. 2014, 14, 483-494.

65. Pierce, G.L.; Warren, G.L.; Mikkelsen, R.L.; Linker, H.M. Effects of Soil Calcium and pH on Seed Germination and Subsequent Growth of Large Crabgrass (Digitaria sanguinalis). Weed Technol. 1999, 13, 421-424.

66. Chidumayo, E.N. Effects of Woocarbonizationon on Soil and Initial Development of Seedlings in Miombo Woodland, Zambia. For. Ecol. Manag. 1994, 70, 353-357.

67. Cely, P.; Gasco, G.; Paz-Ferreiro, J.; Mendez, A. Agronomic Properties of Biochars from Different Manure Wastes. J. Anal. Appl. Pyrol. 2015, 111, 173-182.

68. Major, J. A Guide to Conducting Biochar Trials-International Biochar Initiative; 2009; pp. 1-30. Available online: www.biochar-international.org (accessed on 23 September 2020).

69. Rondon, M.A.; Lehmann, J.; Ram\&rez, J.; Hurtado, M. Biological Nitrogen Fixation by Common Beans (Phaseolus vulgaris L.) Increases with Bio-Char Additions. Biol. Fertil. Soil. 2007, 43, 699-708. [CrossRef]

70. Sarma, B.; Gogoi, N. Germination and Seedling Growth of Okra (Abelmoschus esculentus L.) as Influenced by Organic Amendments. Cogent Food Agric. 2015, 1, 1030906.

71. Gaskin, J.W.; Speir, A.; Morris, L.M.; Ogden, L.; Harris, K.; Lee, D.; Das, K.C. Potential for pyrolysis char to affect soil moisture and nutrient status of a loamy sand soil. In Proceedings of the 2007 Georgia Water Resources Conference; Georgia Institute of Technology: Athens, Greece, 2007.

72. Asai, H.; Samson, B.K.; Stephan, H.M.; Songyikhangsuthor, K.; Homma, K.; Kiyono, Y.; Inoue, Y.; Shiraiwa, T.; Horie, T. Biochar Amendment Techniques for Upland Rice Production in Northern Laos: 1. Soil Physical Properties, Leaf SPAD and Grain Yield. Field Crops Res. 2009, 111, 81-84.

73. Meng, H.; Hua, S.; Shamsi, I.H.; Jilani, G.; Li, Y.; Jiang, L. Cadmium-Induced Stress on the Seed Germination and Seedling Growth of Brassica napus L., and Its Alleviation through Exogenous Plant Growth Regulators. Plant Growth Regul. 2009, 58, 47-59. [CrossRef]

74. Solaiman, Z.M. Use of Biochar for Sustainable Agriculture. J. Integr. Field Sci. 2018, 15, 8-17.

(C) 2020 by the authors. Licensee MDPI, Basel, Switzerland. This article is an open access article distributed under the terms and conditions of the Creative Commons Attribution (CC BY) license (http://creativecommons.org/licenses/by/4.0/). 